\title{
FUTURE DEVELOPMENT TRENDS AND Chalenges in Production AND SOCIAL SYSTEMS
}

\author{
Buchmeister, B.; LeBER, M.; PALCIC, I. \& VUJICA HERCOG, N.
}

Abstract: The great challenge facing us today and in the future is best described as continuous renewal. This is an imperative that applies not only to business but also to science, government and society as a whole. In a fast changing global scenario all economies are being reshaped, businesses are being repositioned, green investments are growing and consumers are calling for cleaner world economy. High-speed, efficient and low-cost communication and the associated vastly increased availability of information have accelerated the process of market globalization and consequently intensified competition and increased the pressure on companies to improve productivity. The ability to change, to respond quickly and to be involved in shaping the changes that are taking place is more important than ever. An important first step is to take a systematic look at the future, in all its many aspects, and to examine what the implications are for today's strategies.

In the chapter a holistic view of the development, changes and new directions in different economic areas (general trends, energy trends, materials and technology trends, transport, education, environment, customers, products, organization, security etc.) within a new full world context and vision is presented. The fair goal of the economy is to sustainably improve human wellbeing and quality of life. We have to change the current economic model using new vision and new measures to create a more sustainable and desirable future which cannot be based on the overconsumption. Reducing the dependency of our society on raw materials and energy consumption through increased material efficiency and innovative, resource-efficient product ideas are promising concepts for the future.

Key words: emerging research, sustainable development, trends, competition, technology
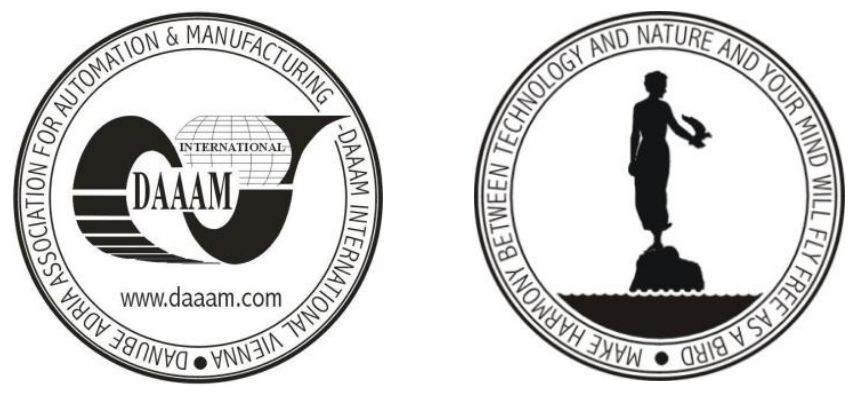

Authors' data: Buchmaister, B[orut]; Leber, M[arjan]; Palcic, [Iztok]; Vujica - Hercog, [Natasa], University of Maribor, Faculty of Mechanical Engineering, Smetanova 17, SI-2000 Maribor, Slovenia, borut.buchmeister@um.si, marjan.leber@um.si, iztok.palcic@uni-mb.si, natasa.vujica@uni-mb.si

This Publication has to be referred as: Buchmeister, B[orut]; Leber, M[arjan]; Palcic, [Iztok] \& Vujica - Hercog, [Natasa] (2013) Future Development Trends and Challenges in Production and Social Systems, Chapter 04 in DAAAM International Scientific Book 2013, pp. 111-132, B. Katalinic \& Z. Tekic (Eds.), Published by DAAAM International, ISBN 978-3-901509-94-0, ISSN 1726-9687, Vienna, Austria

DOI: $10.2507 /$ daaam.scibook.2013.04 
Buchmeister, B.; Leber, M.; Palcic, I. \& Vujica Herzog, N.: Future Development T...

\section{Introduction}

In 1947 experts predicted that by the year 2000: helicopter or gyrocopter will be in every garage, we will travel by nuclear powered aircrafts and trains, all diseases will be cured, we will have 30 hour work week, Moon base will exist and we will live on Mars (Welles, 2005). Since then we have seen first landing on the Moon, growing gap between rich and poor, robots replacing people and instant global communication including the World Wide Web. So, predictions can be very unsure and sometimes totally in a wrong way.

In a fast changing global scenario all economies are being reshaped, businesses are being repositioned, green investments are growing and consumers are calling for cleaner world economy. High-speed, efficient and, above all, low-cost communication and the associated vastly increased availability of information have accelerated the process of market globalization and consequently intensified competition and increased the pressure on companies to improve productivity.

One of the most critical and influential trends is the population change. The world population now is approximately 7 billion, expected to reach 8.3 billion in 2030. Rural-urban migration is speeding up and the average age will also rise from 28 today to 34 in 2030 (Kim, 2010).

Climate change and finite resources are beginning to affect every organisation big or small, public, private or non-profit and irrespective of its geographic location or type of business. The terms 'corporate sustainability' and 'corporate social responsibility' are already dominating board rooms of many public and private organisations within the efforts in developing "green" scorecards and other tools to motivate responsible decision making, seeking that highest level of achievement in sustainability (Simpson \& Hancock, 2013).

Society is made up of organizations, groups and individuals. Each is more than a simple unit of economic exchange. Organizations have responsibility for the general well-being of society beyond short-term economic self-interest. Corporate social responsibility concerns the quality of interaction between a business and surrounding society. At the level of the individual, this means devising jobs and work patterns which allow individuals to contribute their talents without undue stress. At a group level, it means recognizing and dealing honestly with employee representatives. This principle also extends beyond the boundaries of the organization. Any business has a responsibility to ensure that it does not knowingly disadvantage individuals in its suppliers or trading partners.

Businesses are also a part of the larger community, often integrated into the economic and social fabric of an area. Increasingly, organizations are recognizing their responsibility to local communities by helping to promote their economic and social well-being (Slack et al., 2010).

Transition from high to low carbon and more sustainable economies has begun. It is therefore no longer a matter of choice for organizations to go green or continue doing business as usual. It is - in fact - a business imperative to incorporate environmental sustainability in all their operations. The regulatory requirements for 
protecting the environment are becoming ever more stringent and the consumer demands for eco-friendly products and services are at all-time high.

Examples of current and emerging research in this area include:

- Eco-efficiency: Using operations management tools to reduce environmental impact, based on the integration of environmental impact measurement into manufacturing or service operations management;

- Product stewardship: Analysis of closed-loop supply chains, eco-labelling, green sourcing, carbon foot-printing, design for the environment;

- Sustainable technology: Analysis of novel operational problems faced by organizations that develop or adopt new products or services in areas such as renewable energy, energy efficiency, green chemicals, organic agriculture, sustainable mobility, or green building;

- Sustainable development: Application and adaptation of operations management concepts and tools in the effective provision of products and services to the "bottom of the pyramid."

Being sustainable means combining a holistic approach with sustainability. Holism is a requirement which has to be redefined every day. It means shaping the present in the knowledge of traditions, with courage for new ideas and responsibility for the future. The term sustainability has to be augmented by political, structural, economic and social dimensions. Only if sustainability is defined in this way it can support the growth of economies - even and especially in a view of the current economic situation (Müller \& Glutsch, 2007).

The ability to change, to respond quickly and - even better - to be involved in shaping the changes that are taking place is thus more important than ever. But the questions as to how this is to be done and which direction to take simply raise further questions. An important first step to take if these questions are to be answered is to take a systematic look at the future, in all its many aspects, and to examine what the implications are for today's strategies (Constanza, 2009).

\section{Development Trends}

Trends, currents and fashions abound in today's world (Berner, 2004). We are going to focus here, above all, on those trends that are relevant from a business and life-style viewpoint (normally present in western developed economies) - trends affecting society, politics, economics, the environment, technology, customers and competitors, as listed in Table 1. Only the most evident changes (developments) are mentioned.

Economy trends show that the global power of US economy is slowly, but constantly decreasing. New countries ("BRIC" group) are taking the leading position. We are faced with the transfer of global wealth and economic power mainly from West to East (Fig. 1). 
Buchmeister, B.; Leber, M.; Palcic, I. \& Vujica Herzog, N.: Future Development T...

\begin{tabular}{|l|l|}
\hline & Continued strong growth in the world's population \\
\hline Growing health awareness \\
\hline Demographic change - more older people \\
\hline Higher costs of private provision for ill health and old age \\
\hline Global consciousness \\
\hline Increasing terrorism in a wide variety of forms / an increasing need for security \\
\hline & Life-long learning \\
\hline Edutainment - entertaining, technology-assisted learning \\
\hline Flexibility with regard to working hours and leisure time and in society as a whole \\
\hline Income polarization, double-income families \\
\hline $\begin{array}{l}\text { Reduced constancy in our working lives, with some people having more than one job } \\
\text { at the same time }\end{array}$ \\
\hline Fewer jobs for low-skilled workers \\
\hline Increasing mobility (with slower growth than before) \\
\hline Changing values \\
\hline Increasing liberalization and deregulation \\
\hline Decreasing importance of borders and distances \\
\hline Decreasing influence of local politics \\
\hline Growing constraints as a result of debt \\
\hline Increasing scope for different interpretations of statutory conditions \\
\hline Reinterpretation of intellectual property \\
\hline Improved resolution of international conflicts \\
\hline Improvement of conditions for business, leading to higher employment \\
\hline Increasing productivity, increasing automation \\
\hline Growth in service industries \\
\hline Greater capital mobility \\
\hline Increasing globalization \\
\hline More frequent relocation of businesses, depending on conditions for business \\
\hline
\end{tabular}




\begin{tabular}{|l|l|}
\hline & Standardized, process-based buyer-vendor relationships \\
\hline IT infrastructure as the new backbone for communication \\
\hline Increased efficiency as a result of intelligent solutions \\
\hline Well-informed customers \\
\hline Outsourcing / partnering \\
\hline Rapidly growing importance of electronic, mobile and real-time business \\
\hline $\begin{array}{l}\text { New purchasing criteria (e.g. self-explanatory products, ease of operation and plug- } \\
\text { and-play functionality) }\end{array}$ \\
\hline Changing mentality: ordered today, delivered tomorrow \\
\hline & Reduced costs / increased productivity \\
\hline Lower barriers to entry in new fields of business as a result of electronic media \\
\hline Global marketing of small and medium-sized enterprises \\
\hline Improved knowledge management to steal a march on the competition \\
\hline \multirow{2}{*}{} & New competitors from other industries \\
\hline Shorter life cycles of products and services \\
\hline Shorter duration and effect of unique selling points \\
\hline Many small, incremental innovations as incentives to consumers to purchase \\
\hline Intensive price wars for market share \\
\hline Growing importance of brand and image \\
\hline
\end{tabular}

Tab.1. Major observed trends

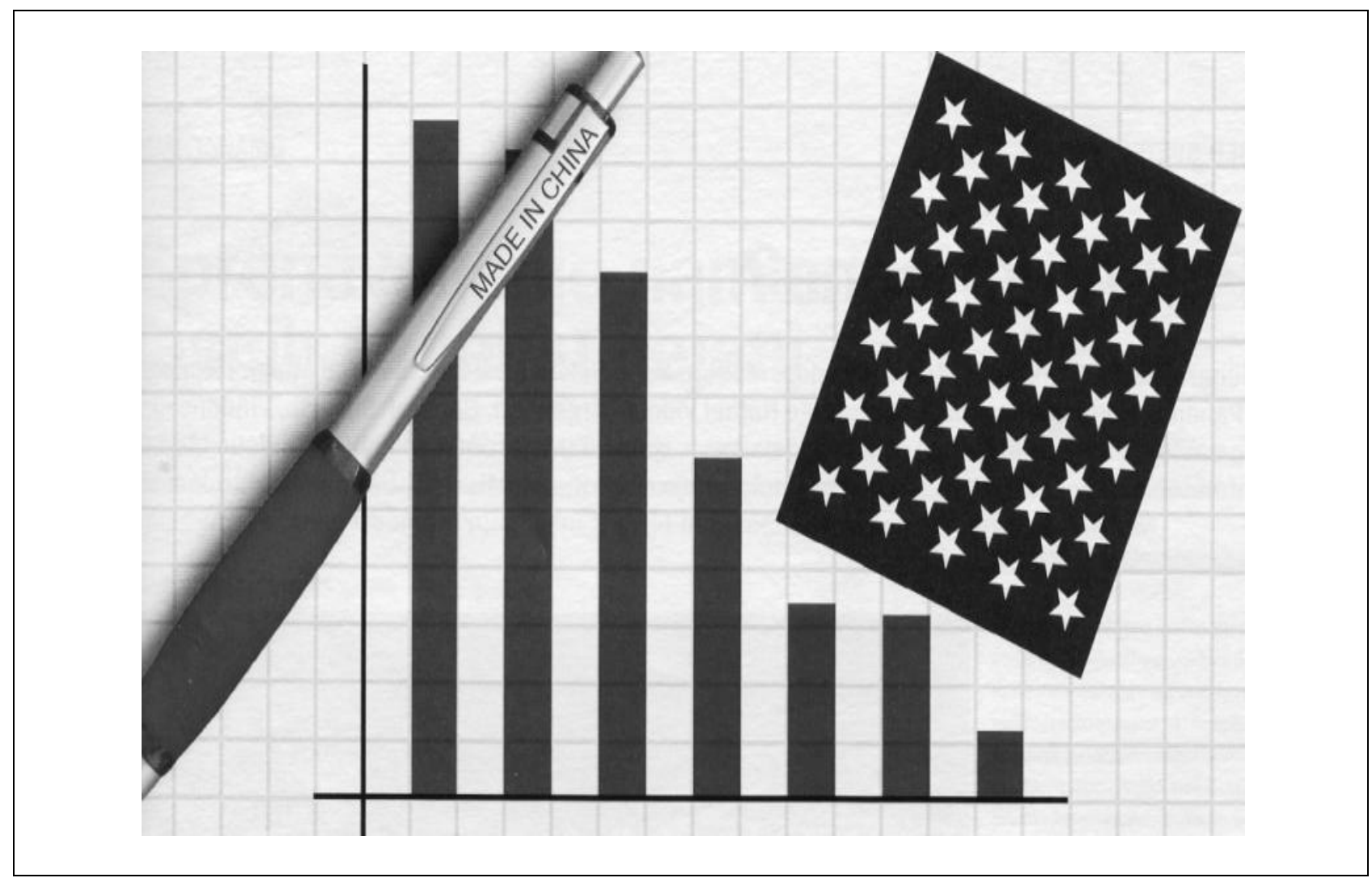

Fig. 1. Reducing global power of the leading economy (Mekina, 2011) 
The pace of technological progress in today's industrial society is essentially dictated by microelectronics. Many of today's products now contain microprocessors and memory chips. Up to now the storage capacity and performance of microprocessors has doubled every 18 months. This rate was predicted by the former chief executive of Intel, Gordon Moore, back in the sixties, and has been known as Moore's law ever since (Fig. 2).

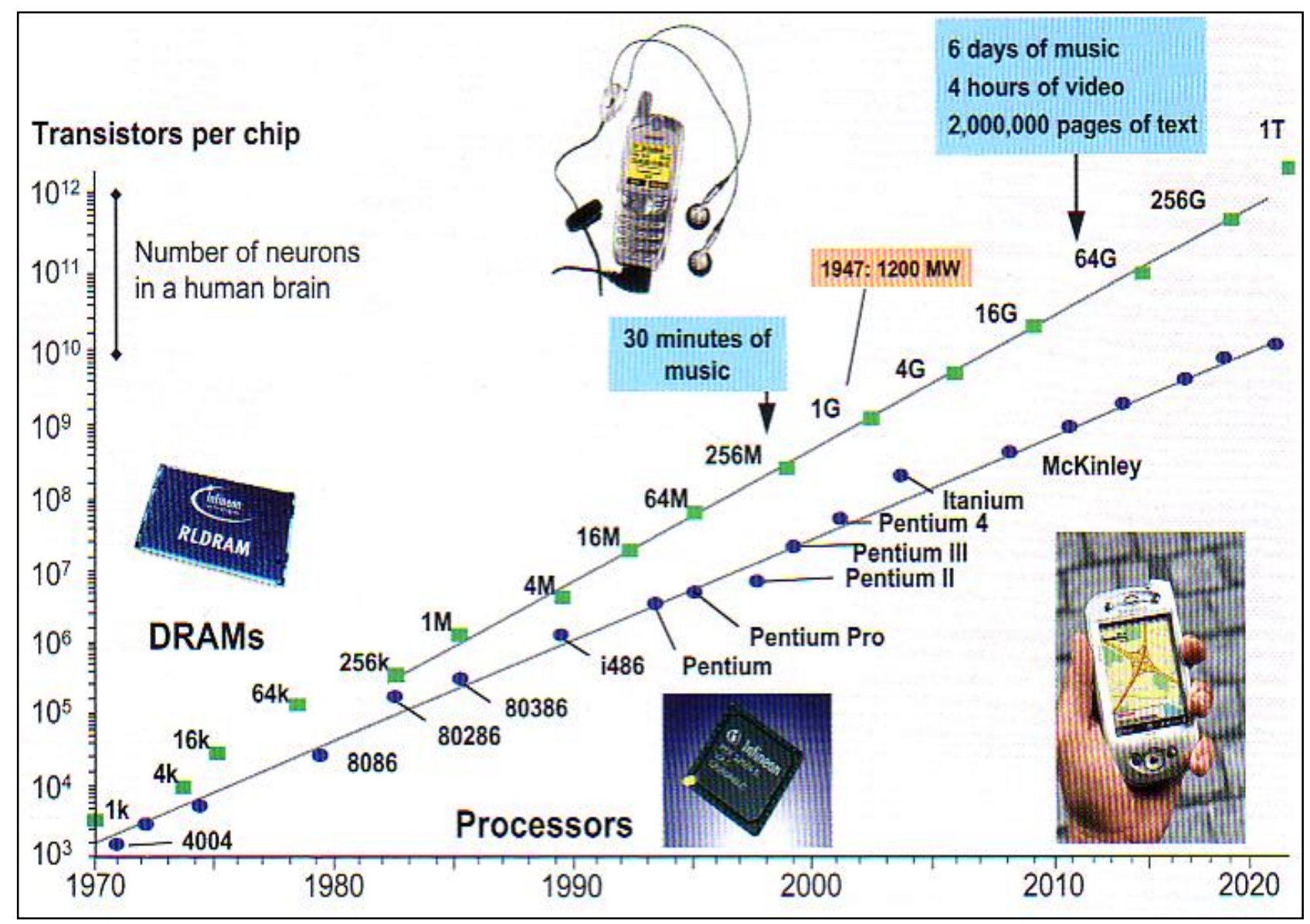

Fig. 2. Moore's law in 1970-2020 (Berner, 2004)

Computers are going to get much smaller, inexpensive, last even longer, and even become part of everyday items. A table, our clothing, and even our bodies can become computers. Eyewear computers will record our lives and they will make iPhones obsolete. We'll be able to log our lives and summon up conversations from the past. But generally the watch will supplant the phone as primary display and interface.

The computer of the year 2020 will be able to capture everything we read ( 20 $\mathrm{GB})$, hear (300 GB) and see (100 TB) in a year. If Moore's law continues to apply beyond the year 2020, the processing power of machines will eventually exceed that of humans. Software alone will then decide whether computers also become more intelligent than us. This knowledge has given new impetus to the development of artificial intelligence and self-learning systems. 
The capacity of our senses is in no way overtaxed by new technologies, as shown in Table 2. If you add up the maximum possible bandwidths that can be picked up by each of our senses, you get a total bandwidth of around $220 \mathrm{Gbps}$, but when it comes to transmission from the senses to the brain, we can "only" manage a bandwidth of around $250 \mathrm{Mbps}$. Signals that go beyond the capacity of our senses and cannot be passed to the brain are simply omitted. Technologies such as MP3 for music and MPEG2 and MPEG4 for video permit similarly high rates of data compression for transmission.

\begin{tabular}{|l|c|c|}
\hline Senses & Bandwidth of receptors & Neural transmission \\
\hline Eyes & $200 \mathrm{Gbps}$ & $200 \mathrm{Mbps}$ \\
\hline Ears & $4 \mathrm{Mbps}$ & $2 \mathrm{Mbps}$ \\
\hline Skin & $1,5 \mathrm{Gbps}$ & $10 \mathrm{Mbps}$ \\
\hline Tongue & $150 \mathrm{Mbps}$ & $11 \mathrm{Mbps}$ \\
\hline Nose & $20 \mathrm{Gbps}$ & $30 \mathrm{Mbps}$ \\
\hline Total (sum) & $>220 \mathrm{Gbps}$ & $\approx 250 \mathrm{Mbps}$ \\
\hline
\end{tabular}

Tab. 2. The capacity of human perception

Here we have to mention a possibility of direct brain interfaces. We (and everything to everything) could be wirelessly connected to computers at some point in the future. A direct brain interface will mean "typing" a document with our minds, thinking of a command and making it happen, and even imaging something and then printing it on a 3-D printer (Brandon, 2013). People will embed sensors and electronic components directly in their bodies. This will allow people to have better insight, hour to hour, and day to day, on the state of their bodies (data such as heart rate, blood oxygen and blood sugar levels), and thus monitor their health and trigger a medical response. Machine learning and big data will allow us to understand this data and the medicine we need to fix our diseases.

Pharmaceuticals will be precisely delivered at the molecular level within or around a diseased cell which means more effective treatments while reducing unwanted side effects. The ability to cheaply sequence genomes means we will solve a lot of diseases. Normally, such high-tech procedures will accelerate the rich-poor gap. We are at the beginning of an unpleasant wave for rich people, because governments will tend to tax the rich to resolve this rich-poor gap (Hof, 2013).

Advanced digital technology is essential for global competition. World trade volume will increase dramatically between now and 2030. That means the interdependency among countries will increase. Without flexibility and adaptability in organization and process, global companies will have difficulty surviving. 
Buchmeister, B.; Leber, M.; Palcic, I. \& Vujica Herzog, N.: Future Development T...

\subsection{Sustainable Development}

Critical global needs are: clean, safe inexpensive water, sustainable agriculture and food production, simple low cost communication, locally produced energy for industry, transportation and communication, and technology to produce products for local customers (Welles, 2005).

The need for sustainable development came as a response to growing concerns over how economic growth often was associated with environmental damage. The triple bottom line concept addresses the importance of integrating social and economic dimensions to sustainable development to achieve environmental progress. More recently, sustainable development has been suggested that a more consistent analytical breakdown is to distinguish four domains of economic, ecological, political and cultural sustainability. Although the idea of sustainable development has been widely accepted as a common wish, there is little guidance about its practical implementation.

Manufacturing has delivered wonderful economic success globally, and enabled many to access the products that improve our lives. These economic and social goods have been delivered simultaneously with negative environmental and social impacts. We agree that the manufacturing sector can learn to balance economic, social and environmental impacts. The next stages of development for the manufacturing sector will form a new industrial revolution and the key dimensions of that revolution are discussed later. Possible solutions that will allow manufacturing to be a net-positive contributor are explained, which form a framework for long term industrial sustainability.

Sustainability addresses the intended products of an operation as well as any other consequences, creating two major areas of output concern (Simpson \& Hancock, 2013):

- Pollution. Polluting of air, soil, and water brings long-term consequences potentially greater than the short-term value creation releasing the pollution. Although societies have struggled with control of pollution for centuries, the recent accumulation of carbon emissions in the atmosphere has raised new alarm. Linked to global climate change, these emissions result from fossil-fuel burning operations that power much of the world's transportation and energy infrastructure.

- Disposal. Disposal of intended products after use can be problematic if this last phase of their life cycle is not carried out in a manner consistent with a longterm sustainability.

We can think of sustainability within three levels. Achieving the first level means "getting the basics right" with the system as it is, such as recycling whenever possible. The second level is "learning to think sustainably". This thinking requires assessing the impact of decisions across both an operation and its broader supply chain partners, with a view to incorporating new lean and sustainable practices 
whenever possible. The third and top level of sustainability involves benchmarking, auditing, and governance to bring clarity to the environmental impact of the organization's practices.

Discussion of sustainable development occurs not only among world governments, academics and non-governmental organizations, but also in industry. By 2050, the global industrial system is targeted by international agreements and governments to double its output while only using $50 \%$ of current resources and generating $20 \%$ of current $\mathrm{CO}_{2}$. This represents a new industrial revolution, requiring new approaches which we term collectively Industrial Sustainability. New approaches to production are said to be green if they are sustainable. Industrial sustainability now appears to be moving up the management agenda in lots of organizations. However, despite this increasing awareness, many challenges for academics and practitioners are still to be solved.

\section{Changes in the Observed Fields}

Let's take a systematic look at the future, in all its many aspects, and to examine what the implications are for today's strategies.

\subsection{Materials}

Materials and resources have shaped cultural history as no other technology has. New material technology paves the way for progress in other technological areas. Some examples here are new liquid crystals for organic light-emitting diodes, ceramics for innovative coatings in power plant construction, new glasses for the optical industry, nano-materials, new metals and polymers for applications in medical technologies and materials for the realization of innovative concepts in chip technologies. New materials also offer a high potential for sustainable development, such as the use of renewable resources and replacement of environmentally harmful substances (Müller \& Glutsch, 2007).

For new materials we may expect to have the characteristics similar to living organisms. A growing trend in biomimicry is the creation of non-living structural materials that will also have the capacity to heal themselves when cut, torn or cracked. Self-healing materials which can repair damage without external human intervention could give manufactured goods longer lifetimes and reduce the demand for raw materials, as well as improving the inherent safety of materials. Another field is organic electronics where we use organic materials such as polymers to create electronic circuits and devices. Making them will be extremely cheap compared with traditional processes (King, 2013).

Recycling of materials is another good example of biomimicry, because recycling is an effort to mirror nature's theme of repeating cycles of transformation (Simpson \& Hancock, 2013). 


\subsection{Energy}

Electrical energy is an input of almost any modern operation. However this input often raises troubling questions of sustainability. We can predict that global energy consumption will rise by 40 to $50 \%$ between now and 2030. It is easy to say that the future of the world heavily depends on how successfully we solve the two main present energy challenges: securing the supply of reliable and affordable energy, and effecting a rapid transition to a low-carbon, efficient and environmental friendly system of energy supply.

The EU wants to obtain one fifth of its energy from renewable sources by 2020 . This 20 percent target is realistic for the final energy generation of electricity, heat and bio fuel. 700 million tonnes of carbon dioxide could be avoided each year in this way. At the same time, the EU countries would consume fewer fossil-fuels equivalent to 250 million tonnes of oil and thus greatly increase their security of supply. The ambitious 20 percent target for total energy consumption requires similarly concerted efforts to be made for power generation from renewable energies (Müller \& Glutsch, 2007).

A central question is how such a development can be achieved at low social costs, high innovation dynamics and in accordance with the demands of liberalized power market. Studies show that the application of technology-specific support instruments combined with long-term price guarantees results in both high growth at comparably low social costs and sustainable innovation dynamics in renewable electricity technologies.

The priority integration of renewable energies reduces the demand for conventional power. The most expensive power station will no longer be price competitive and all this will result in considerable price reductions on the spot market but also in cost savings for all customers. Energy efficiency brings opportunities for climate protection.

The use of fossil fuels is responsible for almost 80 per cent of global carbon dioxide emissions and increasing efforts are being made world-wide to reduce greenhouse gases. The decarbonisation of coal using carbon capture and storage will play a leading role for fossil-based power station technologies. The direct and later the indirect co-firing of biomass in fossil-fuelled power stations could become significantly more relevant. Of the other renewable energies, wind, ocean wave energy and photovoltaic may continue to be growth markets. But commercial-scale solar thermal power also has good market prospects. New technologies also include micro fuel cells, which may run on hydrogen, alcohol or human waste.

Spent-fuel recycling and breeding uranium-238 into new fissile material will extend already-mined uranium resources for centuries while dramatically reducing the volume and long-term toxicity of wastes, whose radioactivity will drop below the level of the original uranium ore on a timescale of centuries rather millennia. This will make geological disposal much less of a challenge (and arguably even unnecessary) and nuclear waste a minor environmental issue compared to hazardous wastes produced by other industries (King, 2013). 


\subsection{Ecology}

Ecology is good business! As soon as this becomes an accepted reality, the forces of capitalism and human greed will take over and clean up the environment much more effectively than any political green movements, consumption curtailing and redirection or cultural re-education (Zeleny, 2009).

Water scarcity is a worsening ecological problem in many parts of the world due to competing demands from agriculture, cities and other human uses. Where freshwater systems are over-used or exhausted, desalination from the sea offers nearunlimited water but a considerable use of energy. Emerging technologies offer the potential for significantly higher energy efficiency in desalination or purification of wastewater, potentially reducing energy consumption by $50 \%$ or more (King, 2013). These new approaches will help at rapid urbanization and water quality degradation.

New technologies that convert the unwanted $\mathrm{CO}_{2}$ into saleable goods can potentially address both the economic and energetic shortcomings of conventional strategies. One of the most promising approaches will use biologically engineered photosynthetic bacteria to turn waste $\mathrm{CO}_{2}$ into liquid fuels or chemicals, in low-cost, modular solar converter systems. These systems address one of the main environmental constraints on biofuels from agricultural or algal feedstock, and could supply lower carbon fuels for automobiles, aviation or other big liquid-fuel users.

The processes of recycling, resource recovery, material reduction, product reuse, remanufacture and systems redeployment lead to innovation and the reinstatement of the business life cycle.

\subsection{Environment}

It is evident for the people that the higher their standard of living, the more critical the situation becomes for the environment. We have to do everything within our power to protect the environment and conserve resources. This includes examining every stage of a product's life cycle with a view to conserving resources and promoting sustainability and then adapting it (Fig. 3).

For a product to be truly sustainable, it needs to be healthy for consumers, safe for workers who make the product, and not harmful to the ecosystems and communities that interact the product throughout its life cycle (Berner, 2004).

There are many sides to sustainable product design. Miniaturization saves materials. Modular designs allow faulty parts to be replaced subsequently. Platform concepts facilitate subsequent upgrading with more powerful components. Appropriate design creates durable and long-lasting products. The individual components of a product must be easy to replace, dismantle and separate and increasingly easy to recycle. In the future all products, secondary substances and residual waste will have to be recyclable (Buchmeister et al., 2011).

More and more people live in cities and the number will continue to grow. Many of them will move to increasingly large cities. By 2025 the world's urban population will grow from today's 3.5 billion to 4.5 billion, while the rural population will increase very slightly from 3.4 to 3.5 billion (Abele, 2013). The United Nations 
estimate that by the year 2050 about $75 \%$ of all humanity will live in cities. But cities are highly diverse. They all share one aspect, namely the matter of how quality of life is taken into account. This is vital for the development of the inhabitants in their local environment and key to the future of the overall system. Cities are facing increasing challenges for the future, above all with regard to climate change and supplies of energy and raw materials, economic development and social harmony.

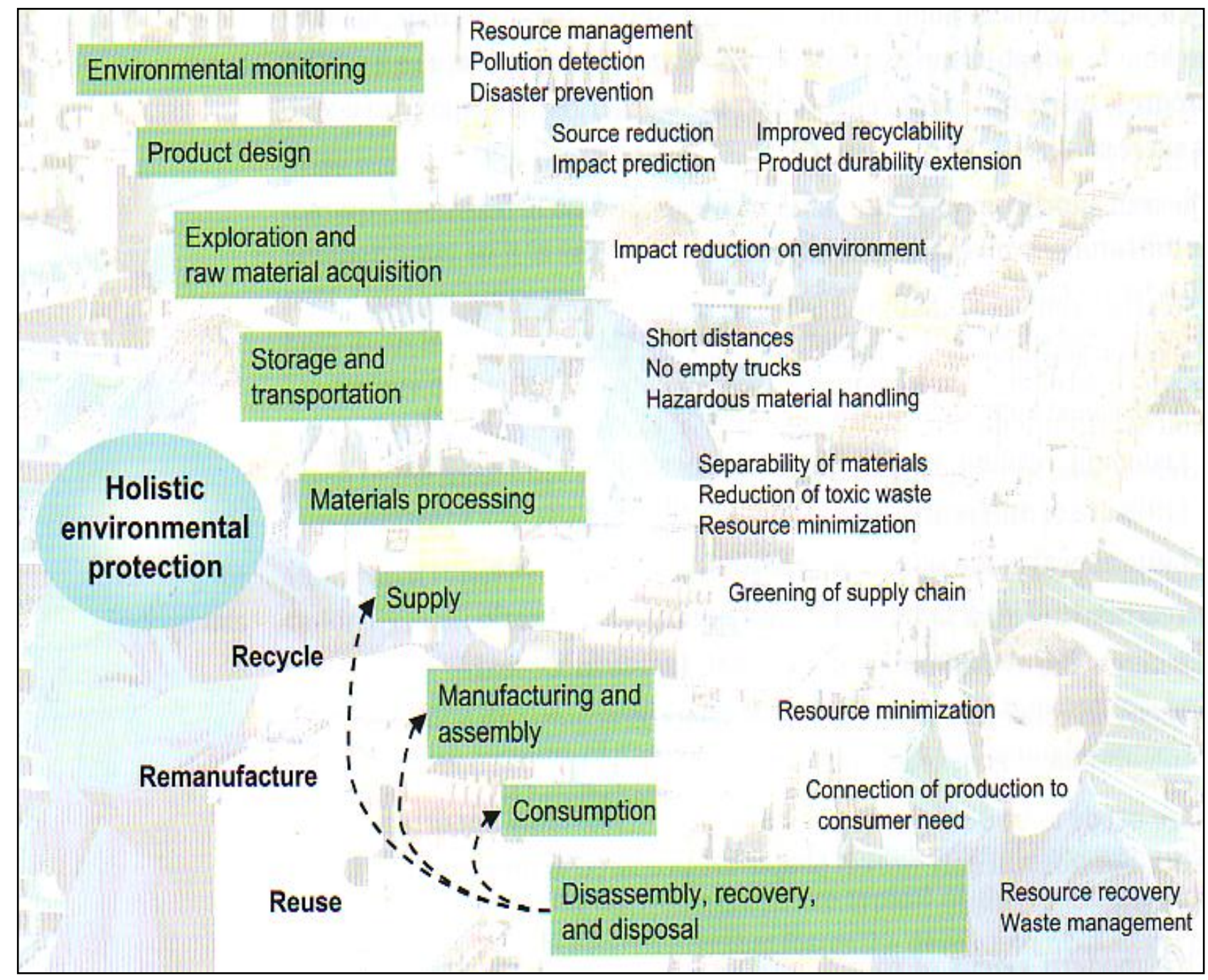

Fig. 3. Environment-conscious product life cycle (Berner, 2004)

\subsection{Technology}

New challenges need new technologies to tackle them. Technology has been one of the main engines of economic development since the industrial revolution (Zeleny, 2009). Any technology can be divided into several clearly identifiable components: hardware, software and brain-ware. These three components are interdependent and equally important. New technologies will be a result of new knowledge or the innovative application of existing knowledge. Some of them will have the potential to disrupt or create entire industries.

Globalization, growing demand for services, new organizational models - the working world in industry is rapidly changing. Researchers investigated the impact of 
three highly differentiated technologies on industrial work of the future: Biotechnology, Nanotechnology and Ambient Intelligence, referring to ubiquitous information and communication technologies. Robots in the future will be more common than phones and tablets today. Nanotechnology will enable the development of self assembling devices at the atomic level. 3-D printing will revolutionize the economics of manufacturing. We believe that technology innovation is the most important key for sustainable growth.

Fig. 4 shows some of the fields that will be associated even more closely with biotechnology in the future. For example, the production of pure human dietary proteins (with a greater percentage of essential amino acids) based on the application of biotechnology to molecular nutrition can deliver health benefits such as muscle development, managing diabetes or reducing obesity. With modern genomic techniques we will be able to determine at the gene sequence level the vast number of naturally consumed proteins which are important in the human diet.

Technology will give us new developed, efficient tools to get work done individually that once required large organizations. Machine learning will add intelligence to advanced equipment. Machine intelligence will transform everything from communications and computing to medicine, manufacturing, and transportation. Big data and sensors everywhere will be useful in combination with machine learning. But for these systems to get smart, it will take as long as for a human. We will not see a Moore's Law for acceleration of the smartness of these algorithms (Hof, 2013).

Technology trends can be predicted more easily and with a greater probability of success than general trends because they are more independent of interfering factors. They are also reproducible and easier to get to grips with. But they change the world in just the same way as the general trends.

Technologies are neither bad nor good; it is how they are used that defines them. Important question is: "Will the technology damage or improve our quality of life?" Technology has to be managed by managers and customers, not simply designed by engineers. The managerial perspective on technology has been so far missing (Zeleny, 2009). Two predictions have proven accurate and will become even more acute in the future. Thus the shortage of expert staff - in particular trained engineers, scientists and economists - will become even more critical as a result of the identified trends. Those less qualified will find it increasingly difficult to find work even in the manufacturing industries.

Some professions will get a new role in production systems. For example: industrial engineers will still focus on value stream improvement, but not only in manufacturing. Administrative, product development, customer service and logistical processes offer huge improvement potential. In the future the industrial engineers will penetrate into the departments for product and process development and innovation management, where are the higher opportunities to reduce costs, eliminate waste and improve quality than in production (Kosturiak, 2009). 


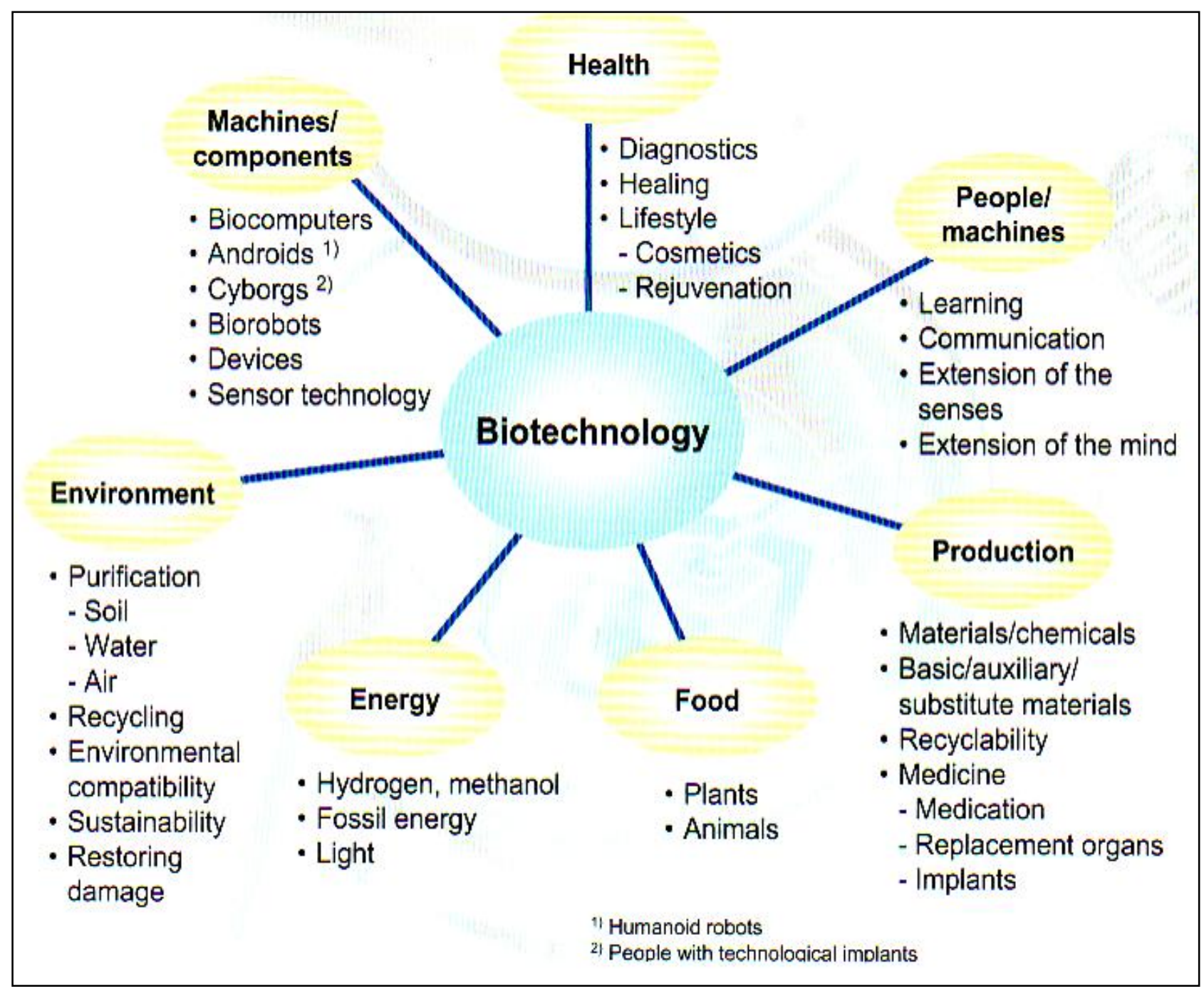

Fig. 4. Biotechnology-fields for the future (Berner, 2004)

\subsection{Organization of Business Processes}

Productivity, flexibility and quality are essential competitive factors, closely related to the way business processes are organized within the company. Organizational innovations are therefore increasingly regarded as the key to successful process management (Müller \& Glutsch, 2007).

Innovation must generate something new for the customer life - simplification, risk elimination, convenience, better price, fun, image and emotions, style or environmental friendliness (Kosturiak, 2009).

Sustainable businesses use measures of progress that clearly acknowledge the goal of sustainable human well-being. Sustainable businesses:

- Replace nationally and internationally produced items with products created locally and regionally.

- Take responsibility for the effects they have on the natural world.

- Do not require exotic sources of capital in order to develop and grow. 
- Engage in production processes that are human, worthy, dignified, and intrinsically satisfying.

- Create objects of durability and long-term utility whose ultimate use or disposition will not be harmful to future generations.

- Change consumers to customers through education (IISD, 1998).

The market's needs and expectations of performance objectives will vary. The extent to which an operation meets market requirements will also vary. In addition, market requirements and the operation's performance could change over time (Fig. 5). Bitcoins could eventually replace the digital (or paper) currency we all use. Manufacturers will bear increased responsibility for how their products are used. We are already familiar with extended warranty periods, product liability and manufacturers' obligation to take products back, and, as time goes on, environmental issues and recyclability will increasingly have to be taken into account as well. The role of the manufacturer over the entire product life cycle is changing, and manufacturers' overall responsibilities for their products are increasing significantly (Berner, 2004).

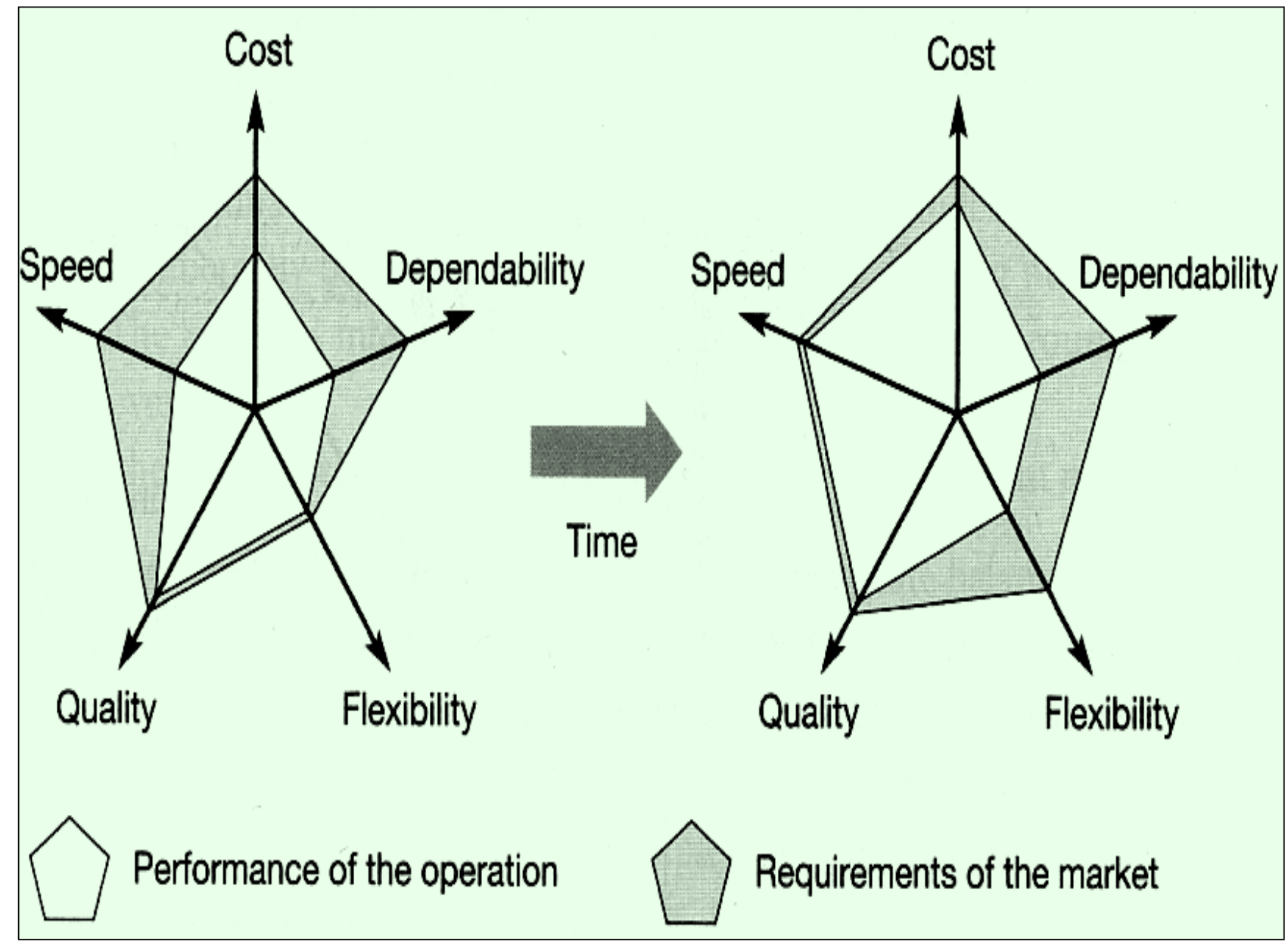

Fig. 5. Customers' needs and operation's performance changes (Slack et al., 2010) 
Buchmeister, B.; Leber, M.; Palcic, I. \& Vujica Herzog, N.: Future Development T...

In recent years, many companies have experienced significant market changes which have and which will affect their business fundamentally and irreversibly. But we have to keep in mind that what works in one part of the world may not be effective in other parts. In the future a lot of new ways of doing business will appear. Development from e-business to e-value-chains, e-companies, e-markets and finally e-world is expected. Open 24 hours a day, 365 days a year, real time business with savings in time and money.

\subsection{Transport}

Increasing global urbanization and the new opportunities opened up by the digital world present us with new challenges in terms of human mobility and transportation of goods. We must understand these trends and developments and give a great deal of thought to supplements and alternatives to existing solutions.

Mobility is the binding agent of social and economic activity. There are several modes of transport available: some that ensure individual privacy, and a number of local public transport media (Abele, 2013).

Transport, especially road and air traffic, represents one of the largest risks from the viewpoint of achieving sustainable development. Several visions for sustainable transport systems have already been developed but so far have failed to gain acceptance because the boundary conditions did not support the necessary technological and psychological changes. But the boundary conditions themselves have changed and this has increased the attraction of introducing a variety of new technologies which may result in a more sustainable transport system if the correct technology choice is made. A sustainable transport system does not force motorized traffic, offers alternatives and interconnects transport services. By providing correct price signals and information, it should result in the selection of the economically and ecologically most advantageous combination of transport means (Müller \& Glutsch, 2007).

Urbanity and urban mobility are to be found in cities of all sizes. The trend toward locally emission-free mobility in cities is already discernible. E-cars, fuel-cell cars and small buses, e-bikes and e-scooters benefit from space advantages in compact urban conditions. They save valuable resources and can be conveniently rented in the context of sharing concepts. Importance for the private automobile is decreasing, but at the same time people expect new opportunities for flexible usage models and mobility services. We have to gain a better understanding of cities as living and operating environments and to draw conclusions for the vehicles and services of tomorrow (Abele, 2013).

Wireless technology can now deliver electric power to moving vehicles. In nextgeneration e-cars, pick-up coil sets under the vehicle floor will receive power remotely via an electromagnetic field broadcast from cables installed under the road. As electricity is supplied externally, these vehicles will need only a fifth of the battery capacity of a standard electric car, and can achieve transmission efficiencies of over $80 \%$ (King, 2013). 
As our means of transportation improve in efficiency, they will produce less pollution and noise. So, emission-free mobility for short, medium, and long distances is an obligate goal. More precise information on traffic volumes and active traffic control will enable traffic flows and route utilization to be optimized (Berner, 2004). The continuing development of driver assistance systems will allow vehicles to be driven entirely autonomously whenever required and deliver a special quality of holistic mobility comfort. The car of the future will know your intentions and predict what you like. Dedicated lanes of traffic will be reserved for self-driving vehicles spaced at precisely defined intervals.

\subsection{Education}

Children these days come into contact with application of the latest technology at a very young age (toys, multimedia etc.). It is becoming apparent that children are likely to start going to school at an earlier age in the future. And there will also be many different types of school to choose from. Education in schools, which is now largely the responsibility of the state, will move in the direction of becoming a profitoriented "school industry". Diplomas are still a signal we will use to assess people. Also, the good schools are already thinking of how they need to change to survive in this environment (Hof, 2013). Open online courses and other online lifelong learning educational sites are great for efficiently distributing information, but thinking outside the box and creatively happens better at universities where you are not just an IP address. All these will permit the financing of research programs into educational science and educational technologies (Mattes \& Emmerson, 2003). Educators, teachers, tutors and trainers are still using much the same methods as they did 50 years ago, and it is time to take a more modern approach (Fig. 6).

Smart learning programs will be able to adapt to the learning speed of the individual on the basis of progress made in order to ensure that the learner remains motivated and is successful. Learning will play a greater role than before for working people also. The future will be defined not by where you went to school but rather by what you know.

\subsection{Security}

At present some additional security concerns arise because of global crime and terrorism. In the search for appropriate protection and security concepts, the need for efficient, high-technology security products and systems becomes of eminent interest. Security research is attracting greater attention in European research and innovation policy, also because legitimate expectations of high value-added potentials are linked to new security technologies. But technical precautions alone will hardly result in security gains. Citizens will accept complete observation by the state. Big brother will know about everything you do, your habits, which Internet sites you attend, where you shop, your medical records, what you download to read or watch. This will feed into custom algorithms to create advertising and inducements for the way you spend your money and just-in-time intervention for the things you need to know 
for upcoming events in your life. So, questions about Loss of freedom and Police state will beat out. Also homes will be more automated to meet all our needs. Acceptance by the population and questions about appropriate societal and organizational framework conditions are the necessary preconditions for the introduction of efficacious security strategies with the help of innovative technology (Müller \& Glutsch, 2007).

Future scenarios include access and surveillance technologies such as digital signatures, smart tags or video recognition systems which play a central role. The elements of the future vision highlight potentials and application areas for, and obstacles to, the utilization of IT to increase security. Security and control problems are the major challenges in wireless technology.

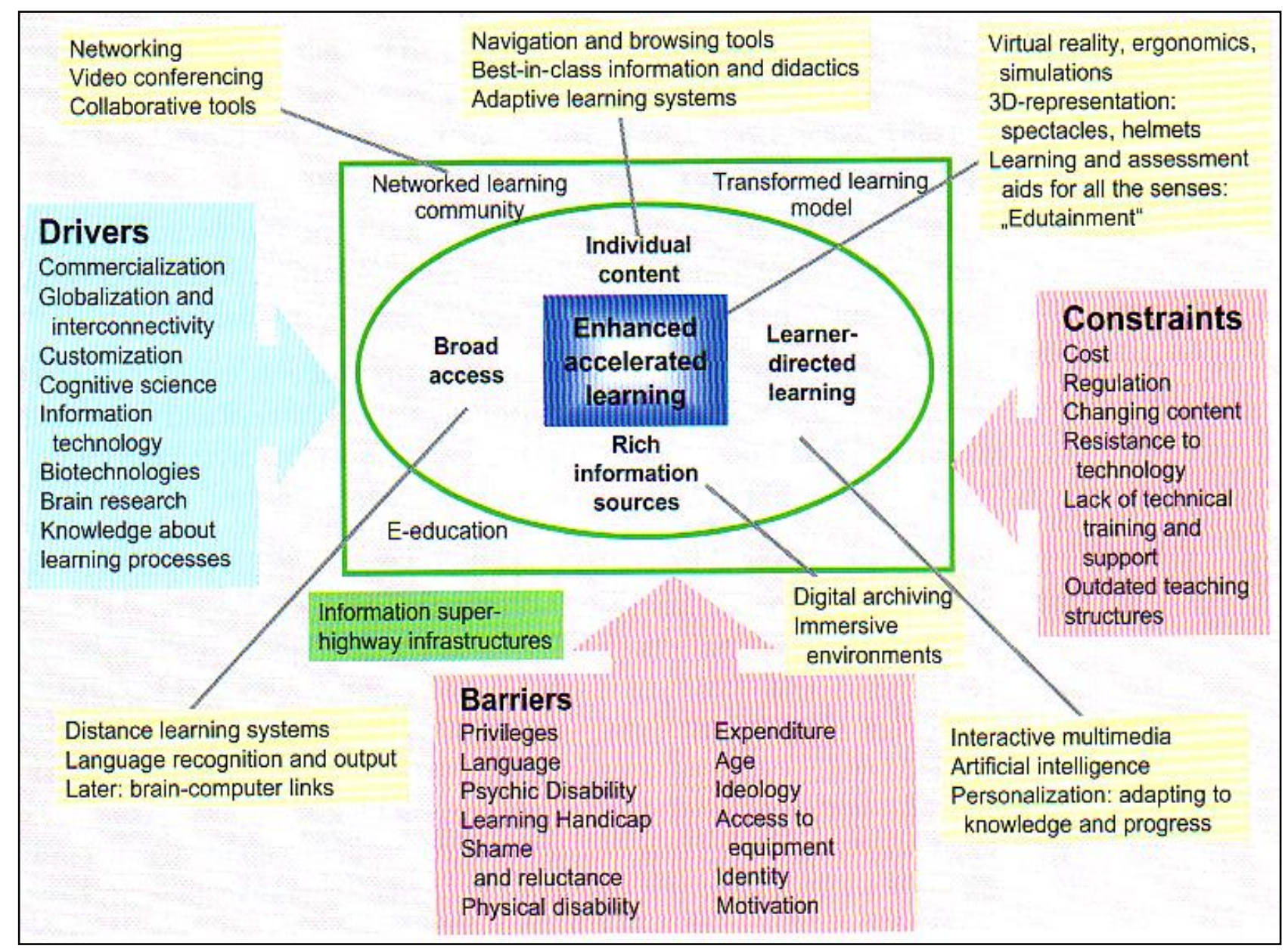

Fig. 6. Technology-assisted education (Berner, 2004)

\section{Conclusion}

In the future, the world will undergo a big transition due to aging society, growing global competition, and energy and environmental problems (Kim, 2010). The most influential factor to the future will be the paradigm shift of science and 
technology. Also, there will be new business opportunities in the areas of ecofriendly energy, water and air.

In this time of change, one is reminded of the words of Charles Darwin, who said: "It is not the strongest of the species that survives, nor the most intelligent, but rather the one that is most adaptable to change." This is now widely known simply as the concept of the "survival of the fittest". The great challenge facing us today and in the future is best described as continuous renewal. This is an imperative that applies not only to business but also to science, government and society as a whole. Innovations change the world, yet innovation cannot flourish without change (Berner, 2004). The key areas of technology that will have most influence on developments in the $21^{\text {st }}$ century are shown in Fig. 7.

We can conclude that our times are characterized by two main features: the increasing networking between different social, political, economic, technical and ecological systems and, at the same time, the growing complexity of the systems involved and their dynamic interactions. Technological change has led to changes in the industrial value chain and to the conditions under which innovation takes place: time and knowledge are increasingly becoming decisive factors. The long-term goal is to redefine environmentalism and occupational health and safety while also demonstrating how these concepts are compatible with new systems of production and consumption that are healthy for workers, environmentally sound, economically viable, and socially accountable.

Principles of sustainable production require that:

- products and services are:

○ safe and ecologically sound throughout their life cycle;

$\circ$ as appropriate, designed to be durable, repairable, readily recycled, compostable, or easily biodegradable;

$\circ$ produced and packaged using the minimal amount of material and energy possible;

- processes are designed and operated such that:

o wastes and ecologically incompatible byproducts are reduced, eliminated or recycled on-site;

o chemical substances or physical agents and conditions that present hazards to human health or the environment are eliminated;

$\circ$ energy and materials are conserved, and the forms of energy and materials used are most appropriate for the desired ends;

$\circ$ work spaces are designed to minimize or eliminate chemical, ergonomic and physical hazard (Hart et al., 2010). 


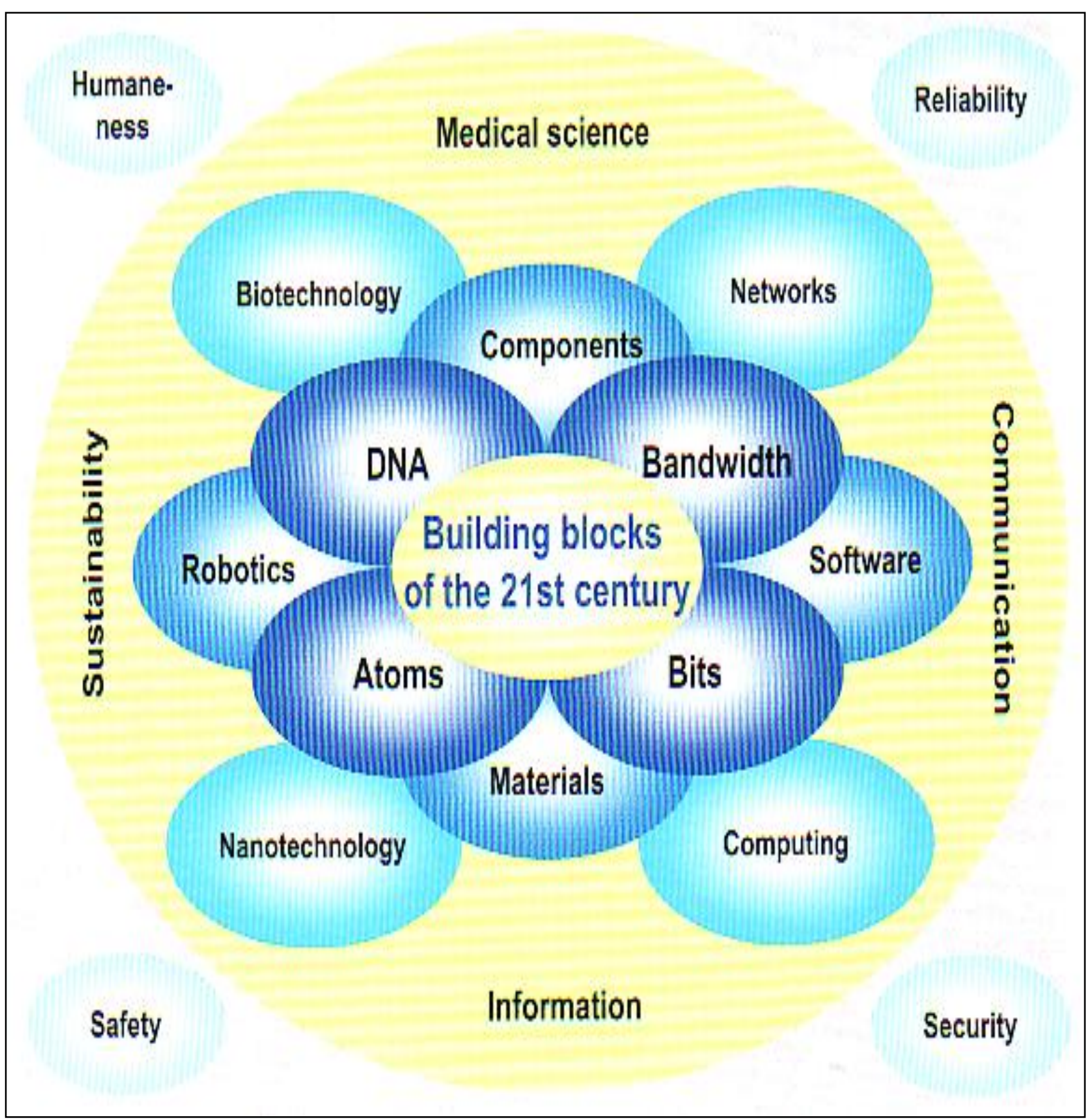

Fig. 7. Building blocks of the $21^{\text {st }}$ century (Berner, 2004)

As a result of the explosive growth in the networking of both people and machines, the speed of progress will increase further. Huge numbers of sensors (cameras, measuring devices and so on) and actuators (robots, machines and so on) will be connected up to the Internet, our global nervous system. It will thus become an artificial system running parallel to reality and analogously to a biological system.

A sustainable community needs to be developed. It needs to be implemented every day by the people who live and work in the community. A sustainable community means many things to the different people who live there. To business owners it means a healthy economy so that their businesses have a place in which to create and sell their products. To parents it means a safe environment in which to 
bring up their children. Everyone wants a secure, productive job to support them. Everyone needs clean air to breathe and clean water to drink.

Companies that do not invest in process evolution, productivity or paradigm-free innovations will soon be closing their doors for the last time. If they do only one of these things, they may just survive, but only those companies that properly face up to all three challenges will be among the winners in the future, creating new value, new jobs, new prosperity for the mankind (Berner, 2004). We have to work together to bring consistent growth and prosperity for all of us, and by doing so we will create a much smarter, safer and more sustainable world.

As depicted in this review, green businesses are thriving around the world and the companies using ecological technologies and environmental friendly processes and practices are reporting tremendous growth - both in terms of turnovers and in profits. Reducing the dependency of our society on raw materials and energy consumption through increased material efficiency and innovative, resource-efficient product ideas are promising concepts for the future. This trend is set to continue or most likely to gain even further momentum as the world prepares itself for the next economy - the sustainable economy!

\section{References}

Abele, R. (2013). The century of cities. Technicity, Vol. 4, No. 1, 12-16 Berner, G. (2004). Management in 20XX, Publicis Corporate Publishing, Erlangen Brandon, J. (2013). The far future: tech trends of 2025, from: http://www.foxnews.com/tech/2013/05/09/far-future-tech-trends-2025/, accessed on 2013-07-07

Buchmeister, B.; Polajnar, A.; Palcic, I.; Pavlinjek, J. \& Vujica-Herzog, N. (2010). Trends of future developments - a step to sustainable production and social systems, Proc. of International Scientific Conference Management of Technology - Step to Sustainable Production (on CD), June 2010, Rovinj, Croatia

Constanza, R. (2009). Toward a new sustainable economy. Real-world economics review, Vol. 49, 20-21

Hart, M.; Hart, E. \& Angelo, J. (2010). Sustainable measures: Sustainable development, from: http://www.sustainablemeasures.com/Sustainability/index.html, accessed on 2011-05-16

Hof, R. (2013). The top 10 future tech trends from 5 top venture capitalists, from: http://www.forbes.com/sites/roberthof/2013/05/23/live-the-top-10-future-tech-trendsfrom-5-top-venture-capitalists/, accessed on 2013-06-28

International Institute for Sustainable Development - IISD (1998). Instruments for change, from: http://www.iisd.org/susprod/principles.htm, accessed on 2011-05-16 Kim, K. (2010). From the future technology perspective: Challenges and opportunities, Proc. of $10^{\text {th }}$ IEEE International Conference on Nanotechnology, August 2010, Seoul, South Korea 
King, D. (2013). The top 10 emerging technologies for 2013 (World Economic Forum), from: http://www.weforum.org/content/top-10-emerging-technologies-2013, accessed on 2013-06-22

Kosturiak, J. (2009). The new role of industrial engineering in a flat world. Acta Mechanica Slovaca, Vol. 13, No. 1, 88-92

Mattes, A. \& Emmerson, B. (2003). $21^{\text {st }}$ century communications, Capstone, Oxford Mekina, I. (2011). Fall of the Empire (in Slovene). Katedra, Vol. 6, No. 3, 22-23

Müller, B. \& Glutsch, U. (2007). Annual Report 2007, Fraunhofer Institute for Systems and Innovation Research ISI, Karlsruhe

Simpson, N. C.; Hancock, P. G. (2013). Practical operations management, Hercher Publishing, Naperville

Slack, N.; Chambers, S. \& Johnston, R. (2010). Operations management, FT Prentice Hall - Pearson, Harlow

Welles, G. W. (2005). Future technology trends, opportunities \& challenges, Humphrey Institute, University of Minnesota, Minneapolis

Zeleny, M. (2009). Technology and high technology - Support net and barriers to innovation. Acta Mechanica Slovaca, Vol. 13, No. 1, 6-19 